Article

\title{
How to Make a Better Magnet? Insertion of Additional Bridging Ligands into a Magnetic Coordination Polymer
}

\author{
Gabriela Handzlik (D) and Dawid Pinkowicz *(D) \\ Faculty of Chemistry, Jagiellonian University, Gronostajowa 2, 30-387 Kraków, Poland; \\ gabriela.handzlik@uj.edu.pl \\ * Correspondence: dawid.pinkowicz@uj.edu.pl; Tel.: +48-16-686-2457
}

Received: 31 July 2018; Accepted: 10 September 2018; Published: 15 September 2018

check for updates

\begin{abstract}
A three-dimensional cyanide-bridged coordination polymer based on $\mathrm{Fe}^{\mathrm{II}}(S=2)$ and $\mathrm{Nb}^{\mathrm{IV}}(\mathrm{S}=1 / 2)\left\{\left[\mathrm{Fe}^{\mathrm{II}}\left(\mathrm{H}_{2} \mathrm{O}\right)_{2}\right]_{2}\left[\mathrm{Nb}^{\mathrm{IV}}(\mathrm{CN})_{8}\right] \cdot 4 \mathrm{H}_{2} \mathrm{O}\right\}_{\mathrm{n}}\left(\mathbf{F e}_{2} \mathbf{N b}\right)$ was modified at the self-assembly stage by inserting an additional formate $\mathrm{HCOO}^{-}$bridge into its cyanide framework. The resulting mixed-bridged $\left\{\left(\mathrm{NH}_{4}\right)\left[\left(\mathrm{H}_{2} \mathrm{O}\right) \mathrm{Fe}^{\mathrm{II}}-(\mu-\mathrm{HCOO})-\mathrm{Fe}^{\mathrm{II}}\left(\mathrm{H}_{2} \mathrm{O}\right)\right]\left[\mathrm{Nb}^{\mathrm{IV}}(\mathrm{CN})_{8}\right] \cdot 3 \mathrm{H}_{2} \mathrm{O}\right\}_{\mathrm{n}} \quad\left(\mathrm{Fe}_{2} \mathbf{N b H C O O}\right)$ exhibited additional $\mathrm{Fe}^{\mathrm{II}}-\mathrm{HCOO}-\mathrm{Fe}^{\mathrm{II}}$ structural motifs connecting each of the two $\mathrm{Fe}^{\mathrm{II}}$ centers. The insertion of $\mathrm{HCOO}^{-}$was possible due to the substitution of some of the aqua ligands and crystallization water molecules in the parent framework by formate anions and ammonium cations. The formate molecular bridge not only shortened the distance between $\mathrm{Fe}^{\mathrm{II}}$ ions in $\mathrm{Fe}_{2} \mathbf{N b H C O O}$ from $6.609 \AA$ to $6.141 \AA$, but also created additional magnetic interaction pathways between the magnetic centers, resulting in an increase in the long range magnetic ordering temperature from $43 \mathrm{~K}$ for $\mathrm{Fe}_{2} \mathbf{N b}$ to $58 \mathrm{~K}$. The mixed-bridged $\mathrm{Fe}_{2} \mathbf{N b H C O O}$ also showed a much broader magnetic hysteresis loop of $0.102 \mathrm{~T}$, compared to $0.013 \mathrm{~T}$ for $\mathbf{F e}_{2} \mathbf{N b}$.
\end{abstract}

Keywords: ferrimagnetism; long-range magnetic ordering; iron(II); octacyanidoniobate(IV); coordination polymers

\section{Introduction}

The rational design of crystalline molecular magnets enables the combination of magnetism (ferromagnetism) with other properties within a single material. The additional functionalities co-exist or are strongly coupled with the magnetic ordering, providing a convenient route to multifunctionality [1]. In terms of future technological applications, it is crucial to develop new strategies towards higher magnetic ordering temperatures in molecular magnets [2] to eliminate the need for expensive cooling resources like liquid helium. Efforts thus far have focused mainly on Prussian blue analogs [3] and cyanido-bridged materials based on hepta- or octacyanidometallates of $4 d$ and $5 d$ metal ions [4,5]. This is due to the ability of $\mathrm{CN}^{-}$to efficiently mediate moderate-to-strong magnetic interactions between the bridged paramagnetic metal ions. Most of the room-temperature molecular magnets are based on $\mathrm{V}^{\mathrm{II}} / \mathrm{V}^{\mathrm{III}}$ and $\mathrm{Cr}$ III metal ions, where the magnetic coupling was found to be the strongest [6-12]. Unfortunately, these compounds are often obtained as amorphous powders and are air-sensitive, therefore, there is still a high demand for air-stable, crystalline, high- $T_{\mathrm{C}}$, molecule-based magnets. One way to achieve this is changing the metal centers (spins and coupling constants). Here, a slightly different approach is proposed based on increasing the number of the closest magnetic neighbors. This approach is dictated by the molecular field theory Equation (1) [13], where the $T_{C}$ depends on three factors: the coupling constant $J_{A B}$ between the two metal centers $\mathrm{A}$ and 
B, the spin values $S_{A}$ and $S_{B}$ and the number of the closest magnetic neighbors $n_{A}$ and $n_{B}\left(k_{B}\right.$ is the Boltzmann constant).

$$
T_{c}=\frac{2 \sqrt{n_{A} n_{B}}\left|J_{A B}\right| \sqrt{S_{A}\left(S_{A}+1\right) S_{B}\left(S_{B}+1\right)}}{3 k_{B}},
$$

The aim of our research was to modify the well-known compound $\left\{\left[\mathrm{Fe}^{\mathrm{II}}\left(\mathrm{H}_{2} \mathrm{O}\right)_{2}\right]_{2}\left[\mathrm{Nb}^{\mathrm{IV}}(\mathrm{CN})_{8}\right] \cdot 4 \mathrm{H}_{2} \mathrm{O}\right\}_{\mathrm{n}}$ $\left(\mathrm{Fe}_{2} \mathrm{Nb}\right)$ [14] by inserting additional bridging ligands connecting the $\mathrm{Fe}^{\mathrm{II}}$ ions in order to increase the number of the nearest magnetic neighbors, and re-inforce the existing long-range magnetic ordering. The implemented changes were similar to the modification of the $\mathrm{Mn}^{\mathrm{II}}-\mathrm{Nb}^{\mathrm{IV}}$ analogue $\left\{\left[\mathrm{Mn}^{\mathrm{II}}\left(\mathrm{H}_{2} \mathrm{O}\right)_{2}\right]_{2}\left[\mathrm{Nb}^{\mathrm{IV}}(\mathrm{CN})_{8}\right] \cdot 4 \mathrm{H}_{2} \mathrm{O}\right\}_{\mathrm{n}}$, described previously [15]. The insertion of formate into the newly obtained mixed-bridged compound $\left\{\left(\mathrm{NH}_{4}\right)\left[\left(\mathrm{H}_{2} \mathrm{O}\right) \mathrm{Fe}^{\mathrm{II}}-(\mu-\mathrm{HCOO})-\mathrm{Fe}^{\mathrm{II}}\left(\mathrm{H}_{2} \mathrm{O}\right)\right]\left[\mathrm{Nb}^{\mathrm{IV}}(\mathrm{CN})_{8}\right] \cdot 3 \mathrm{H}_{2} \mathrm{O}\right\}_{\mathrm{n}}$ $\left(\mathrm{Fe}_{2} \mathbf{N b H C O O}\right)$ led to a very significant increase of the critical temperature $T_{\mathrm{C}}$ from $43 \mathrm{~K}\left(\mathrm{Fe}_{2} \mathbf{N b}\right.$ parent framework) to $58 \mathrm{~K}$, and a larger coercive field.

\section{Results and Discussion}

\subsection{Synthesis and X-ray Crystal Structure Description}

The insertion of additional formate anions into the three-dimensional (3D), CN-bridged parent framework of $\mathrm{Fe}_{2} \mathbf{N b}$ at the self-assembly stage resulted in the formation of $\mathbf{F e}_{2} \mathbf{N b H C O O}$ with mixed $3 d-4 d$ and $3 d-3 d$ metal bridging. The key to its formation was a large excess of ammonium formate in the solution of the building blocks: Mohr's salt and potassium octacyanidoniobate(IV) dihydrate. The formation of the desired product was fully confirmed by single crystal X-ray diffraction structural analysis (sc-XRD; Figure 1 and Table 1), infrared spectroscopy (IR), elemental analysis (EA), and powder X-ray diffraction (PXRD).
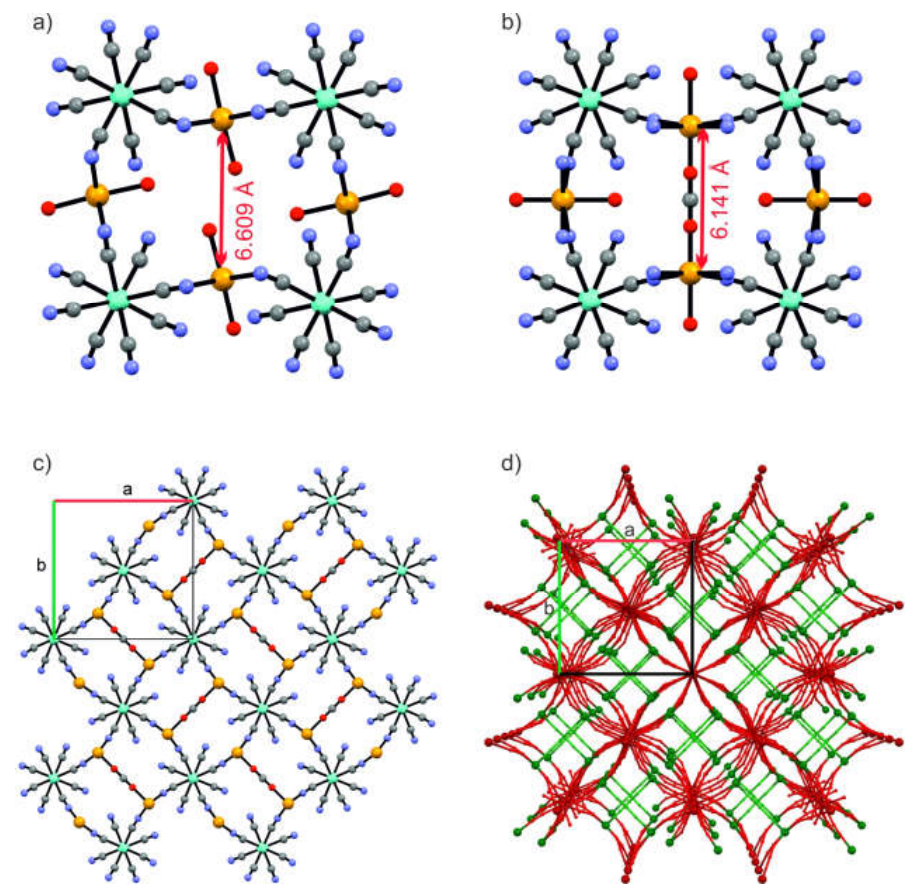

Figure 1. Structural diagrams showing the potential "cavity" between adjacent $\mathrm{Fe}^{\mathrm{II}}$ ions in the parent framework $\mathrm{Fe}_{2} \mathrm{Nb}(\mathrm{a})$, the additional formate bridge occupying the "cavity" in $\mathbf{F e}_{2} \mathbf{N b H C O O}(\mathrm{b})$, a slice of $\mathrm{Fe}_{2} \mathrm{NbHCOO}$ crystal packing parallel to the $a b$ crystallographic plane (c), and a packing diagram presenting the three-dimensional (3D) CN-bridged coordination framework (red) cross-linked by local formate bridges (green) (d). Note: $\mathrm{Nb}$-cyan, $\mathrm{Fe}$-yellow, $\mathrm{C}$-gray, $\mathrm{N}$-blue, and $\mathrm{O}_{\text {formate }}$-red. Hydrogen and oxygen atoms of water molecules have been omitted for the sake of clarity. 
Table 1. Sc-XRD structural, solution and refinement parameters for $\mathrm{Fe}_{2} \mathrm{NbHCOO}$.

\begin{tabular}{|c|c|}
\hline Formula & $\mathrm{C}_{9} \mathrm{HFe}_{2} \mathrm{~N}_{9} \mathrm{NbO}_{7}$ \\
\hline Temperature, $\mathrm{K}$ & 296(2) \\
\hline$\lambda, \AA$ & $0.71073 \AA$ \\
\hline Molecular weight, g/mol & 551.80 \\
\hline Crystallographic system & tetragonal \\
\hline Space group & $I 4 \mathrm{~cm}$ \\
\hline Unit cell & $\begin{array}{l}a=11.8782(12) \AA \\
b=13.2770(14) \AA\end{array}$ \\
\hline Volume $V, \AA^{3}$ & $1873.3(4)$ \\
\hline $\mathrm{Z}$ & 4 \\
\hline Density $\rho_{\text {calc }}, \mathrm{g} / \mathrm{cm}^{3}$ & 1.957 \\
\hline$F(000)$ & 1068 \\
\hline$\theta, \operatorname{deg}$ & $3.4-28.0$ \\
\hline Abs. coeff. $\mu, \mathrm{mm}^{-1}$ & 2.18 \\
\hline Data/parameters / restrains & $1211 / 81 / 8$ \\
\hline$R\left[F^{2}>2 \sigma\left(F^{2}\right)\right]$ & 0.032 \\
\hline$w R\left(F^{2}\right)$ & 0.064 \\
\hline GOF on $F^{2}$ & 1.103 \\
\hline Flack parameter & $0.472(25)$ \\
\hline $\max /$ min resid. density, e. $\AA^{-3}$ & $1.13 /-0.59$ \\
\hline Reflections collected & 13274 \\
\hline Unique reflections & 1211 \\
\hline$R_{\text {int }}$ & 0.048 \\
\hline Completeness, $\%$ & 99.6 \\
\hline
\end{tabular}

$\mathrm{Fe}_{2} \mathrm{NbHCOO}$ is isostructural with its $\mathrm{Mn}^{\mathrm{II}}$ analogue $\left\{\left(\mathrm{NH}_{4}\right)\left[\left(\mathrm{H}_{2} \mathrm{O}\right) \mathrm{Mn}^{\mathrm{II}}-(\mu-\mathrm{HCOO})-\mathrm{Mn}^{\mathrm{II}}\left(\mathrm{H}_{2} \mathrm{O}\right)\right]\right.$ $\left.\left[\mathrm{Nb}^{\mathrm{IV}}(\mathrm{CN})_{8}\right] \cdot 3 \mathrm{H}_{2} \mathrm{O}\right\}_{\mathrm{n}}\left(\mathbf{M n}_{2} \mathbf{N b H C O O}\right)$ [15]. The coordination framework of $\mathbf{F e}_{2} \mathbf{N b H C O O}$ becomes anionic compared to $\mathbf{F e}_{2} \mathbf{N b}$, due to the insertion of negatively charged formate. As such, its electroneutrality is maintained by a simultaneous incorporation of an ammonium cation, which replaces one of the crystallization water molecules present in the parent compound.

Insertion of formate anions causes mild changes in the geometry of the $\mathrm{CN}$-framework of $\mathrm{Fe}_{2} \mathrm{NbHCOO}$, compared to the parent $\mathrm{Fe}_{2} \mathrm{Nb}$. However, a noticeable change occurred between the adjacent $\mathrm{Fe}^{\mathrm{II}}$ centers, where the formate ion was bound (Figure $1 \mathrm{~b}$ ), the $\mathrm{Fe}^{\mathrm{II}} \ldots \mathrm{Fe}^{\mathrm{II}}$ distance was shortened by $0.468 \AA$ (from $6.609 \AA$ to $6.141 \AA$ ). The corresponding change in the $\mathbf{M n}_{2} \mathbf{N b H C O O}$ [15] compared to its $\mathrm{Mn}^{\mathrm{II}}-\mathrm{Nb}^{\mathrm{IV}}$ parent [16] was smaller, shortening by only $0.337 \AA$ (from $6.590 \AA$ to $6.253 \AA$ ). A comparison of the most important distances and angles in $\mathrm{Fe}_{2} \mathbf{N b H C O O}$ and $\mathrm{Fe}_{2} \mathbf{N b}$ is presented in Table 2. The cyanide bridges in $\mathbf{F e}_{2} \mathbf{N b H C O O}$ were slightly less bent compared to $\mathbf{F e}_{2} \mathbf{N b}$, while other structural parameters were quite similar (except for the aforementioned $\mathrm{Fe} \cdots \mathrm{Fe}$ distances). 
Table 2. Comparison of selected distances $(\AA)$ and angles $\left(^{\circ}\right)$ in the parent framework and modified $\mathrm{Fe}_{2} \mathrm{NbHCOO}$.

\begin{tabular}{ccc}
\hline Atom Names & $\mathbf{F e}_{2} \mathbf{N b}$ & $\mathbf{F e}_{2} \mathbf{N b H C O O}$ \\
\hline $\mathrm{Nb} \cdots \mathrm{Fe}$ & 5.409 & 5.461 \\
& 5.508 & 5.480 \\
\hline $\mathrm{Nb} \cdots \mathrm{Fe}_{\mathrm{av}}$ & 5.459 & 5.471 \\
\hline $\mathrm{Fe} \cdots \mathrm{Fe}$ & $6.609(1)$ & $6.141(1)$ \\
\hline \multirow{2}{*}{$\mathrm{Fe}-\mathrm{N}_{\mathrm{CN}}$} & $2.144(2)$ & $2.119(10)$ \\
& $2.175(2)$ & $2.171(10)$ \\
\hline \multirow{2}{*}{$\mathrm{Fe}-\mathrm{N}-\mathrm{C}$} & $154.5(2)$ & $157.8(11)$ \\
& $167.5(2)$ & $170.0(9)$ \\
\hline \multirow{2}{*}{$\mathrm{Nb}-\mathrm{C}-\mathrm{N}$} & $174.6(2)$ & $173.0(10)$ \\
& $176.7(2)$ & $178.4(11)$ \\
\hline \multirow{2}{*}{$\mathrm{Fe}-\mathrm{O}_{\mathrm{aq}}$} & $2.099(3)$ & $2.191(9)$ \\
\hline $\mathrm{Fe}-\mathrm{O}_{\mathrm{HCOO}}$ & $2.130(3)$ & $1.977(9)$ \\
\hline
\end{tabular}

In both $\mathrm{Fe}_{2} \mathbf{N b H C O O}$ and $\mathrm{Fe}_{2} \mathbf{N b}$, each $\left[\mathrm{Nb}^{\mathrm{IV}}(\mathrm{CN})_{8}\right]^{4-}$ was connected to eight nearly octahedral [Fe $\mathrm{Fe}^{\mathrm{II}}(\mathrm{CN})_{4}\left(\mathrm{H}_{2} \mathrm{O}\right) \mathrm{L}$ ] moieties $\left(\mathrm{L}=\mathrm{H}_{2} \mathrm{O}\right.$ for $\mathbf{F e}_{2} \mathbf{N b}$ and $\mathrm{L}=$ formate for $\mathbf{F e}_{2} \mathbf{N b H C O O}$ ). The coordination geometry of $\mathrm{Nb}^{\mathrm{IV}}$ in $\mathrm{Fe}_{2} \mathbf{N b H C O O}$ was slightly closer to an ideal square antiprism than in $\mathbf{F e}_{2} \mathbf{N b}$, according to the continuous shape measure analysis executed using SHAPE software [17]. Conversely, the geometry of the octahedral $\mathrm{Fe}^{\mathrm{II}}$ centers was much more distorted in $\mathrm{Fe}_{2} \mathbf{N b H C O O}$ due to the strain imposed by the bridging formate anion (Figure 1a,b and Table 3), which might lead to a completely different magnetic anisotropy.

Table 3. Analysis of the coordination spheres of $\mathrm{Fe}^{\mathrm{II}}$ and $\mathrm{Nb}^{\mathrm{IV}}$ ions in $\mathbf{F e}_{2} \mathbf{N b}$ and $\mathrm{Fe}_{2} \mathbf{N b H C O O}$.

\begin{tabular}{cccc}
\hline $\mathrm{Nb}^{\mathrm{IV}}$ & Square antiprism (SAPR-8) & 0.192 & 0.113 \\
\hline $\mathrm{Fe}^{\mathrm{II}}$ & Octahedron (OC-6) & 0.161 & 0.562 \\
\hline
\end{tabular}

The insertion of the additional formate bridge into the parent $\mathrm{Fe}_{2} \mathbf{N b}$ framework changed the symmetry from a centrosymmetric $I 4 / m$ to a non-centrosymmetric $I 4 \mathrm{~cm}$. The structure of $\mathbf{F e}_{2} \mathbf{N b H C O O}$ was refined as an inversion twin with the following scales: 0.49(10) and 0.51(10). The asymmetric unit (Figure 2) was comprised of $\mathrm{Nb}^{\mathrm{IV}}$ and $\mathrm{Fe}^{\mathrm{II}}$ ions linked with a $\mathrm{CN}^{-}$ligand (C2N2). The second $\mathrm{CN}^{-}$ ligand (C1N1) in the asymmetric unit connected the $\mathrm{Fe}^{\mathrm{II}}$ ion with the next $\mathrm{Nb}^{\mathrm{IV}}$ ion in the structure. The asymmetric unit also included an aqua ligand coordinated to $\mathrm{Fe}^{\mathrm{II}}(\mathrm{O} 1)$ and half of the bridging formate anion $(\mathrm{C} 3 \mathrm{O} 2)$. There were also two oxygen atoms of the crystallization water molecules (O3 with occupancy 0.5 and $\mathrm{O} 4$ with occupancy 1.0), and a nitrogen atom of the ammonium cation (N3 with 0.5 occupancy in the same position as O3). H-atoms could not be located from the Fourier difference map. The presence of the ammonium cation was confirmed by IR spectroscopy (see below) and is consistent with the elemental analysis (EA) results. 


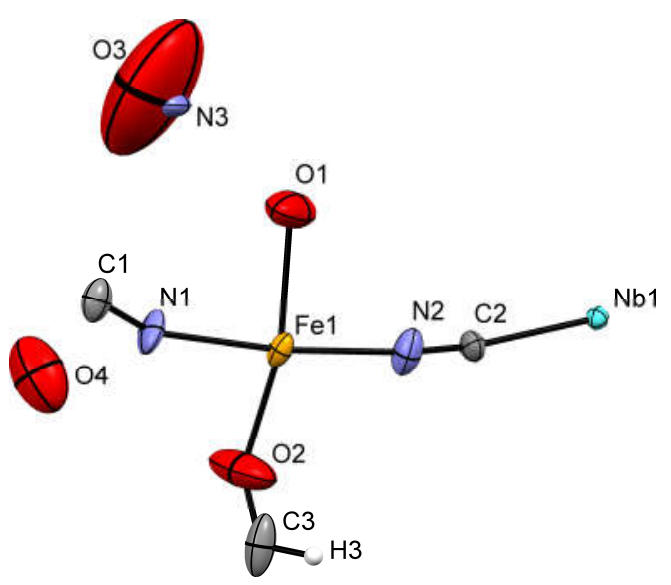

Figure 2. Asymmetric unit of $\mathrm{Fe}_{2} \mathrm{NbHCOO}$.

\subsection{IR Spectroscopy}

The infrared (IR) spectrum of $\mathbf{F e}_{2} \mathbf{N b H C O O}$ (Figure 3) exhibited bands typical for the parent framework: two bands characteristic for stretching $\left(3576 \mathrm{~cm}^{-1}\right)$ and bending $\left(1635 \mathrm{~cm}^{-1}\right)$ vibrations of $\mathrm{O}-\mathrm{H}$, and a strong band characteristic for stretching vibrations of $\mathrm{CN}^{-}$ligands $\left(2141 \mathrm{~cm}^{-1}\right)$. Additional specific bands as compared to the parent framework indicate the presence of the inserted formate anions $\left(1584 \mathrm{~cm}^{-1}, 1383 \mathrm{~cm}^{-1}, 1365 \mathrm{~cm}^{-1}\right.$ and $\left.812 \mathrm{~cm}^{-1}\right)$ and the ammonium cations $\left(3261 \mathrm{~cm}^{-1}\right.$ and $\left.1403 \mathrm{~cm}^{-1}\right)$.

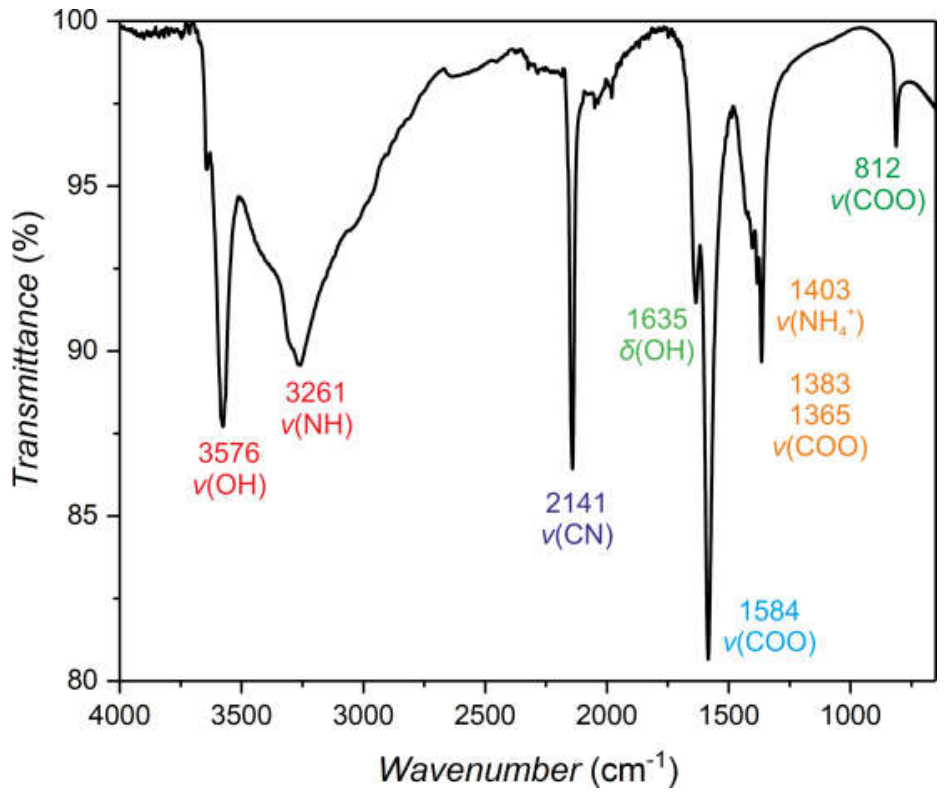

Figure 3. IR spectrum of $\mathrm{Fe}_{2} \mathrm{NbHCOO}$.

\subsection{Identity and Purity Confirmation by Powder X-ray Diffraction}

The identity and purity of the bulk sample of $\mathrm{Fe}_{2} \mathbf{N b H C O O}$ was confirmed by powder X-ray diffraction measurements (Figure 4). The experimental PXRD diffraction patterns were in very good agreement with the simulated results from the sc-XRD structural model obtained at room temperature. 


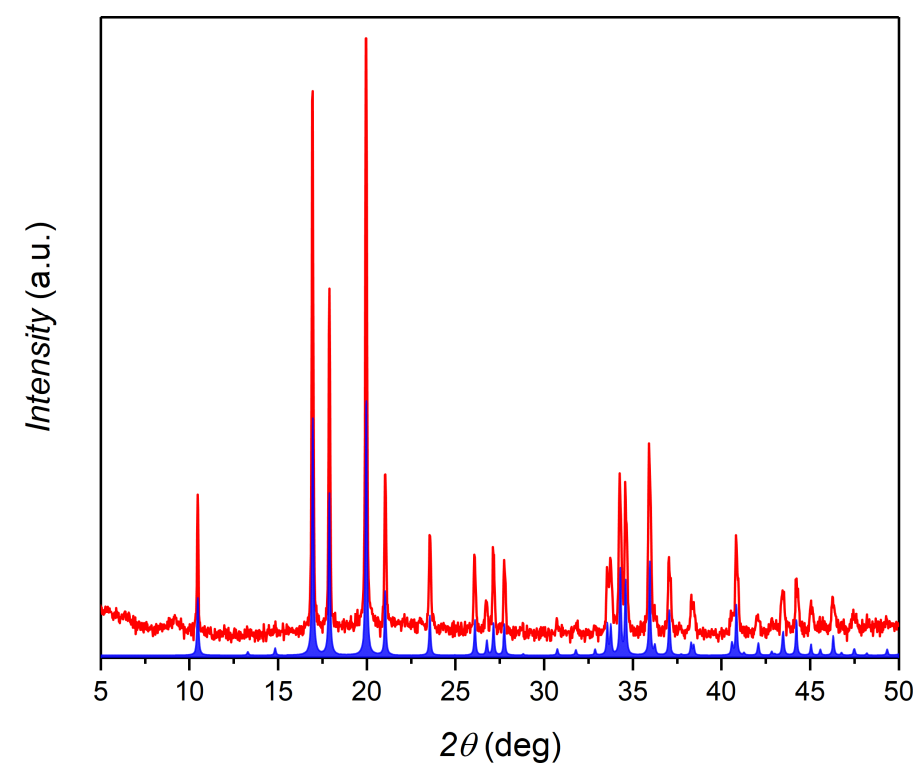

Figure 4. Experimental (red) and simulated from the single-crystal structural model (blue) powder X-ray diffraction patterns for $\mathbf{F e}_{2} \mathbf{N b H C O O}$ (the broad peak at $8^{\circ}$ is from the glass capillary-the sample holder).

\subsection{Magnetic Properties}

The shape of the $\chi T(T)$ dependence for $\mathbf{F e}_{2} \mathbf{N b H C O O}$ recorded in the $2-300 \mathrm{~K}$ range at $0.1 \mathrm{~T}$ magnetic field (Figure 5) suggests the presence of a long-range magnetic ordering in this system below $70 \mathrm{~K}$ (discussed below). The experimental $\chi \mathrm{T}$ value at $300 \mathrm{~K}$ of $8.31 \mathrm{~cm}^{3} \cdot \mathrm{K} \cdot \mathrm{mol}^{-1}$ was slightly lower than the expected $9.02 \mathrm{~cm}^{3} \cdot \mathrm{K} \cdot \mathrm{mol}^{-1}$ for two $\mathrm{Fe}^{\mathrm{II}}(S=2)$, assuming $g_{\mathrm{Fe}}=2.4$, and one $\mathrm{Nb}^{\mathrm{IV}}\left(S=\frac{1}{2}\right)$, assuming $g_{\mathrm{Nb}}=2.0$. This was most probably caused by the presence of antiferromagnetic interactions within the $\mathrm{Nb}^{\mathrm{IV}}-\mathrm{CN}-\mathrm{Fe} \mathrm{II}^{\mathrm{II}}$ coordination framework. $\chi \mathrm{T}$ increased significantly as the temperature was lowered to reach a maximum value of $889 \mathrm{~cm}^{3} \cdot \mathrm{K} \cdot \mathrm{mol}^{-1}$ at $45 \mathrm{~K}$, confirming the long-range magnetic ordering.

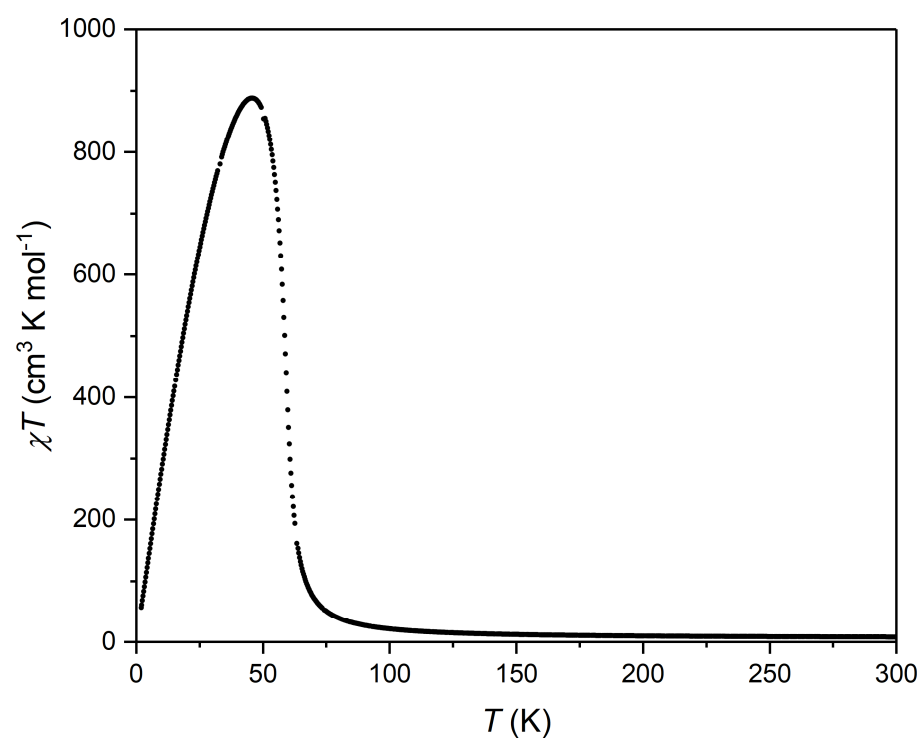

Figure 5. Temperature dependence of the molar magnetic susceptibility and temperature product for $\mathrm{Fe}_{2} \mathrm{NbHCOO}$ at $H=0.1 \mathrm{~T}$.

The magnetization vs. temperature $M(T)$ curves recorded in the zfc-fc (zero field-cooled, field-cooled) modes at $0.3 \mathrm{mT}$ for $\mathbf{F e}_{2} \mathbf{N b H C O O}$ are presented in Figure 6 . The most striking 
feature is the significant increase of the magnetization at $58 \mathrm{~K}$, which constitutes the long-range magnetic ordering temperature $T_{\mathrm{c}}$ for this system. The critical temperature $T_{\mathrm{c}}$ was defined as the $\mathrm{zfc}-\mathrm{fc}$ bifurcation point and was confirmed by the position of the maximum of the AC (alternating current) magnetic susceptibility signal $\chi^{\prime}$ at $57.5 \mathrm{~K}$ (Figure 7). There was essentially no frequency dependence of the in-phase and out-of-phase AC susceptibilities at the magnetic ordering temperature, which supports the claim that the reported compound is a magnetically ordered system. However, a slight frequency drift below $50 \mathrm{~K}$ indicates some dynamic processes taking place in the compound. Understanding this behavior will require further measurements using more advanced techniques (i.e., muon spin spectroscopy).

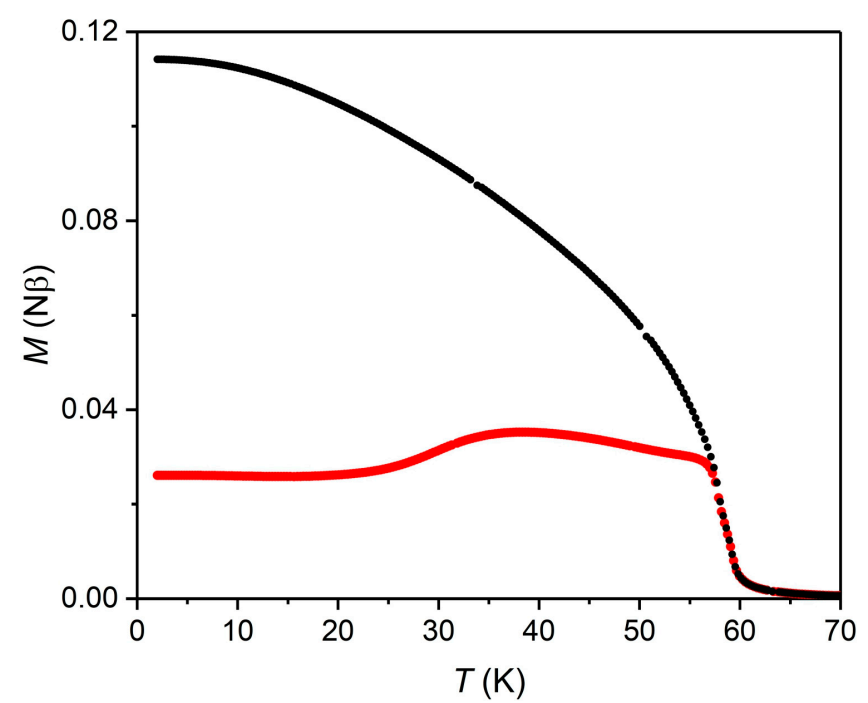

Figure 6. Temperature dependence of the molar magnetization measured in the $\mathrm{zfc}-\mathrm{fc}$ (red and black points, respectively) modes for $\mathrm{Fe}_{2} \mathrm{NbHCOO}$.

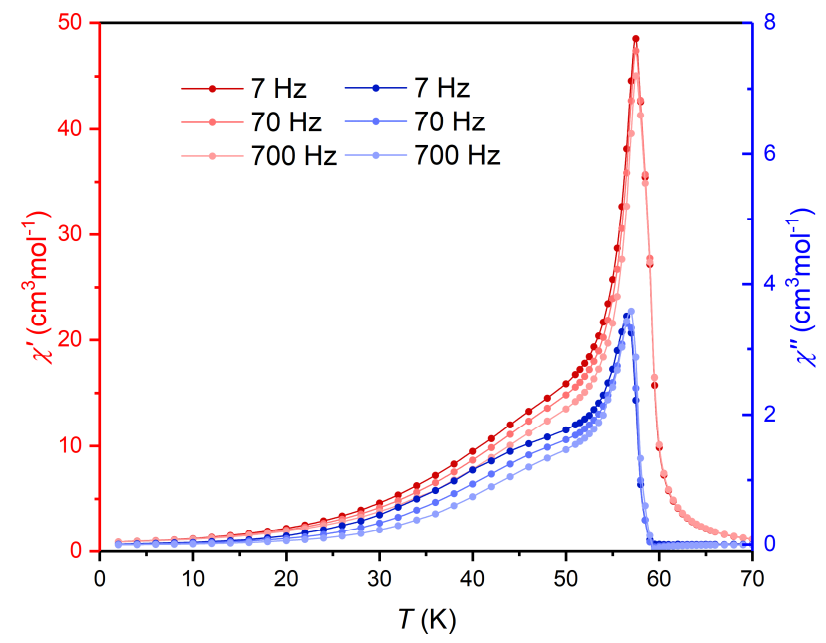

Figure 7. Temperature dependence of the in-phase and out-of-phase AC magnetic susceptibility of $\mathbf{F e}_{2} \mathbf{N b H C O O}$ at $H_{\mathrm{AC}}=0.1 \mathrm{mT}$ and at three different frequencies $(7,70$ and $700 \mathrm{~Hz})$.

The magnetic field dependence of the molar magnetization for $\mathrm{Fe}_{2} \mathbf{N b H C O O}$ (recorded up to $7 \mathrm{~T}$ at $T=2.0 \mathrm{~K}$ ) is presented in Figure 8. The magnetization curve showed a fast increase to circa $4.5 \mathrm{~N} \beta$ at $0.2 \mathrm{~T}$, followed by a further slower increase and a saturation value of ca. $8.8 \mathrm{~N} \beta$ at $7.0 \mathrm{~T}$. This was similar to the value obtained for the parent $\mathrm{Fe}_{2} \mathbf{N b}$ [14], and close to the expected $8.6 \mathrm{~N} \beta$ for two high-spin $\mathrm{Fe}^{\mathrm{II}}\left(S=2, g_{\mathrm{Fe}}=2.4\right)$ antiferromagnetically coupled with $\mathrm{Nb}^{\mathrm{IV}}$ ion $\left(S=\frac{1}{2}, g_{\mathrm{Nb}}=2.0\right)$. This suggests that $\mathrm{Fe}_{2} \mathrm{NbHCOO}$ exhibits long-range ferrimagnetic ordering. $\mathrm{Fe}_{2} \mathrm{NbHCOO}$ exhibited a magnetic hysteresis 
loop (Figure 8, inset) with the coercive field $H_{\mathrm{c}}=102 \mathrm{mT}$ and the remanence $M_{\mathrm{R}}=4.8 \mathrm{~N} \beta$. Both values were much larger than the parent framework $\mathrm{Fe}_{2} \mathbf{N b}\left(H_{\mathrm{c}}=13 \mathrm{mT}\right.$ and $\left.M_{\mathrm{R}}=1.24 \mathrm{~N} \beta\right)$. The significant increase of the magnetic ordering temperature and a larger coercive field/remanence of $\mathrm{Fe}_{2} \mathbf{N b H C O O}$ compared to the parent $\mathrm{Fe}_{2} \mathbf{N b}$ were most likely caused by the inserted bridging formate connecting the neighboring $\mathrm{Fe}^{\mathrm{II}}$ ions. This formate bridge must promote the $\mathrm{Fe}^{\mathrm{II}}$ ions magnetic anisotropy change and most probably additional local ferromagnetic interactions between them, which work in concert with the postulated ferrimagnetic structure of the CN-bridged framework (Figure 9). Nevertheless, an unlikely scenario where strong ferromagnetic ordering within the $\mathrm{Nb}^{\mathrm{IV}}-\mathrm{CN}-\mathrm{Fe}^{\mathrm{II}}$ framework [14] is accompanied by very weak antiferromagnetic interactions through $\mathrm{Fe}^{\mathrm{II}}-\mathrm{HCOO}-\mathrm{Fe}^{\mathrm{II}}$ pairs is also possible. Please note that the $\mathrm{Mn}^{\mathrm{II}}$-based analog $\left\{\left(\mathrm{NH}_{4}\right)\left[\left(\mathrm{H}_{2} \mathrm{O}\right) \mathrm{Mn}^{\mathrm{II}}-(\mu-\mathrm{OOCH})-\mathrm{Mn}^{\mathrm{II}}\left(\mathrm{H}_{2} \mathrm{O}\right)\right]\left[\mathrm{Nb}^{\mathrm{IV}}(\mathrm{CN})_{8}\right] \cdot 3 \mathrm{H}_{2} \mathrm{O}\right\}_{n}$ $\left(\mathbf{M n}_{2} \mathbf{N b H C O O}\right)$ that we recently reported [15] showed a significant lowering of the $T_{\mathrm{c}}$ from $49 \mathrm{~K}$ to $45 \mathrm{~K}$ compared to its $\left\{\left[\mathrm{Mn}^{\mathrm{II}}\left(\mathrm{H}_{2} \mathrm{O}\right)_{2}\right]_{2}\left[\mathrm{Nb}^{\mathrm{IV}}(\mathrm{CN})_{8}\right] \cdot 4 \mathrm{H}_{2} \mathrm{O}\right\}_{\mathrm{n}}\left(\mathbf{M n}_{\mathbf{2}} \mathbf{N b}\right)$ parent framework, due to the antiferromagnetic interactions transmitted through the $\mathrm{Mn}^{\mathrm{II}}-\mathrm{HCOO}-\mathrm{Mn}^{\mathrm{II}}$ motifs.

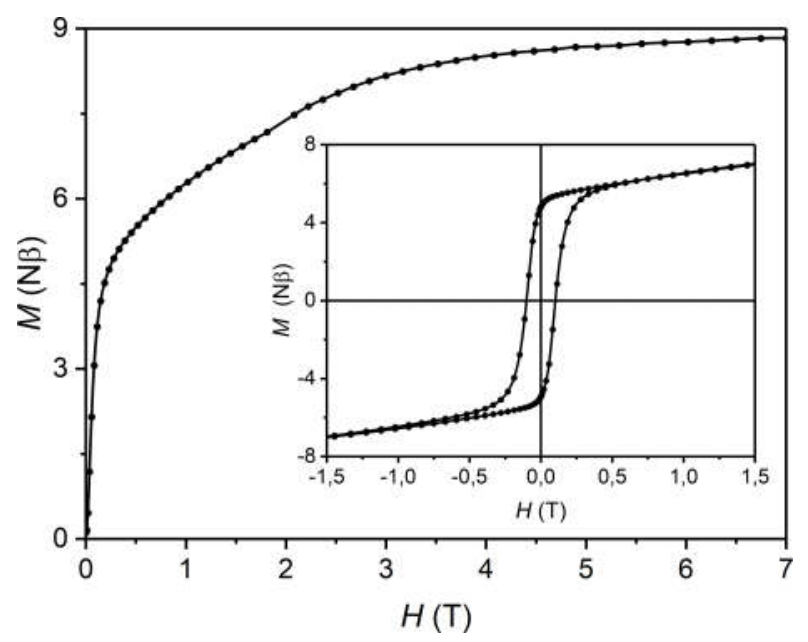

Figure 8. The magnetic field dependence of the molar magnetization of $\mathrm{Fe}_{2} \mathbf{N b H C O O}$ recorded at 2.0 $\mathrm{K}$ in the 0-7 T range and the magnetic hysteresis loop at the same temperature (inset).

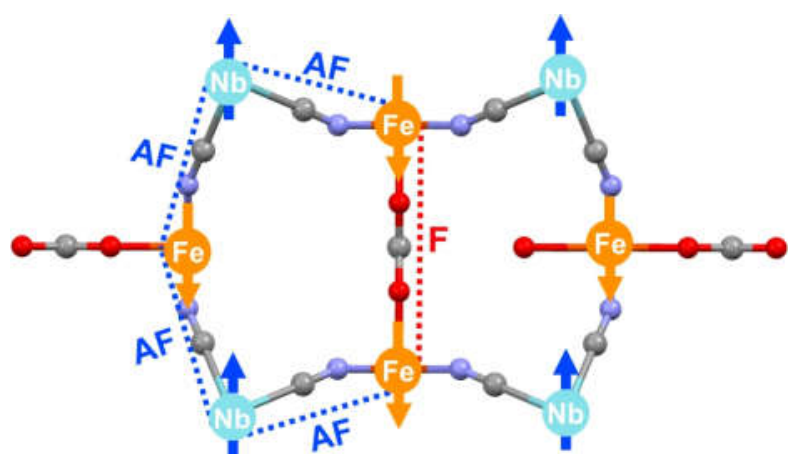

Figure 9. Schematic representation of the postulated ferrimagnetic structure of $\mathrm{Fe}_{2} \mathbf{N b H C O O}$ with an antiparallel alignment of the $\mathrm{Nb}^{\mathrm{IV}}$ and $\mathrm{Fe}^{\mathrm{II}}$ magnetic moments. The ferromagnetic interactions transmitted through the newly introduced $\mathrm{Fe}^{\mathrm{II}}-\mathrm{HCOO}-\mathrm{Fe}^{\mathrm{II}}$ structural motifs work in concert with the antiferromagnetic coupling within the $-\mathrm{Nb}^{\mathrm{IV}}-\mathrm{CN}-\mathrm{Fe}^{\mathrm{II}}-3 \mathrm{D}$ skeleton.

\section{Materials and Methods}

\subsection{Materials}

Chemicals of analytical grade were purchased from commercial sources (Sigma-Aldrich Co., St. Louis, MO, USA) and used as received. $\mathrm{K}_{4}\left[\mathrm{Nb}(\mathrm{CN})_{8}\right] \cdot 2 \mathrm{H}_{2} \mathrm{O}$ was synthesized according to the last reported procedure [18]. All operations were carried out in an ambient atmosphere. 


\subsection{Synthesis of $\left\{\left(\mathrm{NH}_{4}\right)\left[\left(\mathrm{H}_{2} \mathrm{O}\right) \mathrm{Fe} \mathrm{I}_{-}^{I I}(\mu-\mathrm{HCOO})-\mathrm{Fe}^{I I}\left(\mathrm{H}_{2} \mathrm{O}\right)\right]\left[\mathrm{Nb}^{I V}(\mathrm{CN})_{8}\right] \cdot 3 \mathrm{H}_{2} \mathrm{O}\right\}_{n}\left(\mathrm{Fe}_{2} \mathrm{NbHCOO}\right)$}

A water $(160 \mathrm{~mL})$ solution of $\mathrm{HCOONH}_{4}(1.26 \mathrm{~g}, 20.0 \mathrm{mmol})$ with a small amount of ascorbic acid (ca. 10-15 mg) was prepared. Half of the volume of this solution was used to dissolve $\mathrm{K}_{4}\left[\mathrm{Nb}(\mathrm{CN})_{8}\right] \cdot 2 \mathrm{H}_{2} \mathrm{O}(149.1 \mathrm{mg}, 0.30 \mathrm{mmol})$, and the other half was used to dissolve $\left(\mathrm{NH}_{4}\right)_{2} \mathrm{Fe}\left(\mathrm{SO}_{4}\right)_{2} \cdot 6 \mathrm{H}_{2} \mathrm{O}(235.3 \mathrm{mg}, 0.60 \mathrm{mmol})$. After adding the greenish solution of Mohr's salt to the yellow solution of potassium octacyanidoniobiate(IV), the resulting orange mixture was left for one day for crystallization. Dark purple crystals $(60.2 \mathrm{mg}, 35 \%)$ of $\mathbf{F e}_{2} \mathbf{N b O O C H}$ were isolated by repeated decantation with distilled water followed by ethanol $(92 \%)$, and were dried for a short while in air (the compound is slightly sensitive to oxygen and needs to be stored at low temperature). We found $\mathrm{C}, 18.81 ; \mathrm{H}, 2.59 ; \mathrm{N}, 21.40 . \mathrm{C}_{9} \mathrm{H}_{15} \mathrm{Fe}_{2} \mathrm{~N}_{9} \mathrm{NbO} 7(565.87 \mathrm{~g} / \mathrm{mol})$ requires $\mathrm{C}, 19.10 ; \mathrm{H}, 2.67 ; \mathrm{N}$, $22.28 \%$. Slightly lower $\mathrm{N}$ content is caused by the air-sensitivity of the compound. $\mathrm{IR}\left(\mathrm{v}_{\max } / \mathrm{cm}^{-1}\right)$ : $3576 \mathrm{~s} v(\mathrm{OH}), 3261 \mathrm{~s} v(\mathrm{NH}), 2141 \mathrm{~s} v(\mathrm{CN}), 1635 \mathrm{~m} \delta(\mathrm{OH}), 1584 \mathrm{vs} v(\mathrm{COO}), 1403 v\left(\mathrm{NH}_{4}{ }^{+}\right), 1383 \mathrm{~m}$ and $1365 \vee(\mathrm{COO})$, and $812 v(\mathrm{COO})$.

\subsection{Single-Crystal X-ray Diffraction}

The single crystal diffraction data for $\mathrm{Fe}_{2} \mathbf{N b H C O O}$ was collected on a Bruker D8 Quest Eco Photon50 CMOS machine equipped with a Mo K $\alpha$ radiation source and a graphite monochromator $(\lambda=0.71073 \AA$ ). . Measurements were performed at ambient temperature (details in Table 1). Data reduction and unit cell determination were carried out using SAINT and SADABS (Apex3 package). Absorption correction using the multi-scan method was applied for all reflection intensities. The structure was solved using direct methods (Apex3 package). Non-hydrogen atoms were refined anisotropically using weighted full-matrix least-squares on $\mathrm{F}^{2}[19,20]$. The crystallographic data is summarized in Table 1. CCDC $1859396\left(\mathrm{Fe}_{2} \mathbf{N b H C O O}\right)$ contains the supplementary crystallographic data for this paper. This data can be obtained free of charge from the Cambridge Crystallographic Data Centre via ww.ccdc.cam.ac.uk/data_request/cif.

\subsection{Magnetic Measurements}

Magnetic measurements were performed using a Quantum Design MPMS-3 Evercool magnetometer equipped with a $7 \mathrm{~T}$ superconducting magnet. The sample was loaded into a double polypropylene bag and sealed. The magnetic susceptibility was corrected for the diamagnetic contribution of the sample holder and the diamagnetism of the samples themselves using Pascal constants.

\subsection{Other Physical Measurements and Calculations}

Infrared spectra were collected on Nicolet iS 5 FT-IR spectrometer (Thermo Fisher Scientific, Wltham, MA, USA) in the range $4000-650 \mathrm{~cm}^{-1}$. Powder X-ray diffraction experiments (PXRD) were carried out using PANalytical X'Pert Pro MPD diffractometer $(\mathrm{Cu} K \alpha$ radiation, Malvern PANalytical, Royston, UK) at ambient temperature for dry well-ground samples loaded into a narrow diameter borosilicate-glass capillary $(0.7 \mathrm{~mm})$. Elemental analysis was performed using an ELEMENTAR Vario Micro Cube CHNS analyzer (Elementar, Langenselbold, Germany). Continuous shape measure analysis for coordination spheres of $\mathrm{Nb}^{\mathrm{IV}}$ and $\mathrm{Fe}^{\mathrm{II}}$ was performed using the SHAPE software [21]. The results are summarized in Table 3.

\section{Conclusions}

A modification of the structure and magnetic properties of a parent coordination polymer $\mathbf{F e}_{2} \mathbf{N b}$ was performed at the self-assembly stage by "forcing" an additional bridging formate anion into its structure. The formate anion formed direct coordination connections with two adjacent $\mathrm{Fe}^{\mathrm{II}}$ centers within the $\mathrm{CN}$-bridged $\mathrm{Fe}^{\mathrm{II}}-\mathrm{Nb}^{\mathrm{IV}}$ framework. The presence of this additional molecular bridge promoting ferromagnetic interactions between iron(II) centers reinforced the ferrimagnetic 
structure of the $\mathrm{Fe}^{\mathrm{II}}-\mathrm{Nb}^{\mathrm{IV}}$ framework, and made $\mathrm{Fe}_{2} \mathbf{N b H C O O}$ a much better magnet than the parent $\mathbf{F e}_{2} \mathbf{N b}$. Our approach demonstrates a new efficient route towards molecular magnets with higher critical temperatures.

Author Contributions: D.P. conceived and designed the experiments and performed the magnetic measurements; G.H. synthesized the compounds and performed the single crystal XRD structural analysis; and D.P. and G.H. analyzed the data and wrote the paper together.

Funding: This work was funded by the Polish National Science Centre within the Sonata Bis project NO. 2016/22/E/ST5/00055.

Conflicts of Interest: The authors declare no conflict of interest.

\section{References}

1. Pinkowicz, D.; Czarnecki, B.; Reczyński, M.; Arczyński, M. Multifunctionality in Molecular Magnetism. Sci. Prog. 2015, 98, 346-378. [CrossRef] [PubMed]

2. Miller, J.S.; Ohkoshi, S. High-T $T_{\mathrm{c}}$ Ordered Molecular Magnets. In Molecular Magentic Materials. Concepts and Applications, 1st ed.; Sieklucka, B., Pinkowicz, D., Eds.; Wiley: Weinheim, Germany, 2017; pp. 161-186, ISBN 978-3-527-33953-2.

3. Tokoro, H.; Ohkoshi, S. Novel magnetic functionalities of Prussian blue analogs. Dalton Trans. 2011, 40, 6825-6833. [CrossRef] [PubMed]

4. Nowicka, B.; Korzeniak, T.; Stefańczyk, O.; Pinkowicz, D.; Choraży, S.; Podgajny, R.; Sieklucka, B. The impact of ligands upon topology and functionality of octacyanidometallate-based assemblies. Coord. Chem. Rev. 2012, 256, 1946-1971. [CrossRef]

5. Wang, X.-Y.; Avendaño, C.; Dunbar, K.R. Malecular magnetic materials based on 4d and 5d transition metals. Chem. Soc. Rev. 2011, 40, 3213-3238. [CrossRef] [PubMed]

6. Entley, W.R.; Girolami, G.S. High-temperature molecular magnets based on cyanovanadate building blocks: Spontaneous magnetization at 230 K. Science 1995, 268, 397-402. [CrossRef] [PubMed]

7. Imoto, K.; Takemura, M.; Tokoro, H.; Ohkoshi, S. A Cyano-Bridged Vanadium-Niobium Bimetal Assembly Exhibiting a High Curie Temperature of 210 K. Eur. J. Inorg. Chem. 2012, 2649-2652. [CrossRef]

8. Mizuno, M.; Ohkoshi, S.; Hashimoto, K. Electrochemical Synthesis of High- $T_{\mathrm{c}}$, Colored, Magnetic Thin Films Composed of Vanadium(II/III)-Chromium(II) Hexacyanochromate(III). Adv. Mater. 2000, 12, 1955-1958. [CrossRef]

9. Ohkoshi, S.; Mizuno, M.; Hung, G.J.; Hashimoto, K. Magnetooptical Effects of Room Temperature Molecular-Based Magnetic Films Composed of Vanadium Hexacyanochromates. J. Phys. Chem. B 2000, 104, 9365-9367. [CrossRef]

10. Ferlay, S.; Mallah, T.; Ouahés, R.; Veillet, P.; Verdaguer, M. A room-temperature organometallic magnet based on Prossian blue. Nature 1995, 378, 701-703. [CrossRef]

11. Holmes, S.M.; Girolami, G.S. Sol-Gel Synthesis of $\mathrm{KV}^{\mathrm{II}}\left[\mathrm{Cr}^{\mathrm{III}}(\mathrm{CN})_{6}\right] \cdot 2 \mathrm{H}_{2} \mathrm{O}$ : A Crystalline Molecule-Based Magnet with a Magnetic Ordering Temperature above $100{ }^{\circ} \mathrm{C}$. J. Am. Chem. Soc. 1999, 121, 5593-5594. [CrossRef]

12. Hatlevik, Ø.; Buschmann, W.E.; Zhang, J.; Manson, J.L.; Miller, J.S. Enhancement of the Magnetic Ordering Temperature and Air Stability of a Mixed Valent Vanadium Hexacyanochromate(III) Magnet to $99{ }^{\circ} \mathrm{C}(372 \mathrm{~K})$. Adv. Mater. 1999, 11, 914-918. [CrossRef]

13. Ohkoshi, S.-I.; Iyoda, T.; Fujishima, A.; Hashimoto, K. Magnetic properties of mixed ferro-ferrimagnets composed of Prussian blue analogs. Phys. Rev. B 1997, 56, 11642-11652. [CrossRef]

14. Pinkowicz, D.; Podgajny, R.; Pełka, R.; Nitek, W.; Bałanda, M.; Makarewicz, M.; Czapla, M.; Żukowski, J.; Kapusta, C.; Zając, D.; et al. Iron(II)-octacyanoniobate(IV) ferromagnet with TC 43 K. Dalton Trans. 2009, 7771-7777. [CrossRef] [PubMed]

15. Handzlik, G.; Sieklucka, B.; Pinkowicz, D. Cross-linking of cyanide magnetic coordination polymers by rational insertion of formate, cyanide or azide. Dalton Trans. 2018. [CrossRef] [PubMed]

16. Herrera, J.M.; Franz, P.; Podgajny, R.; Pilkington, M.; Biner, M.; Decurtins, S.; Stoeckli-Evans, H.; Neels, A.; Grade, R.; Dromzee, Y.; et al. Three-dimensional bimetallic octacyanidometalates $\left[\mathrm{M}^{\mathrm{IV}}\left\{(\mu-\mathrm{CN})_{4} \mathrm{Mn}^{\mathrm{II}}\left(\mathrm{H}_{2} \mathrm{O}\right)_{2}\right\}_{2} \cdot 4 \mathrm{H}_{2} \mathrm{O}\right]_{n}(\mathrm{M}=\mathrm{Nb}, \mathrm{Mo}, \mathrm{W})$ : Synthesis, single-crystal X-ray diffraction and magnetism. C. R. Chim. 2008, 11, 1192. [CrossRef] 
17. Alvarez, S.; Alemany, P.; Casanova, D.; Cirera, J.; Llunell, M.; Avnir, D. Shape maps and polyhedral interconversion paths in transition metal chemistry. Coord. Chem. Rev. 2005, 249, 1693-1708. [CrossRef]

18. Handzlik, G.; Magott, M.; Sieklucka, B.; Pinkowicz, D. Alternative Synthetic Route to Potassium Octacyanidoniobate(IV) and Its Molybdenum Congener. Eur. J. Inorg. Chem. 2016, 30, 4872-4877. [CrossRef]

19. Sheldrick, G.M. A short history of SHELX. Acta Crystallogr. Sect. A: Found. Crystallogr. 2008, 64, $112-122$. [CrossRef] [PubMed]

20. Sheldrick, G.M. Crystal structure refinement with SHELXL. Acta Crystallogr. Sect. C: Struct. Chem. 2015, 71, 3-8. [CrossRef] [PubMed]

21. Llunell, M.; Casanova, D.; Cirera, J.; Alemany, P.; Alvarez, S. SHAPE v. 2.1; University of Barcelona: Barcelona, Spain, 2013.

2018 by the authors. Licensee MDPI, Basel, Switzerland. This article is an open access article distributed under the terms and conditions of the Creative Commons Attribution (CC BY) license (http:// creativecommons.org/licenses/by/4.0/). 